Çukurova Üniversitesi Mühendislik Mimarlık Fakültesi Dergisi, 31(1), 263-271 ss. , Haziran 2016

Çukurova University Journal of the Faculty of Engineering and Architecture, 31(1), pp. 263-271, June 2016

\title{
Evaluation of Performance and Emission Characteristics of a VCR Diesel Engine Fuelled with Diesel Fuel and Diesel-Biodiesel-Alcohol Blends
}

\author{
Abdulkadir YAŞAR ${ }^{1}$, Ali KESKİN ${ }^{* 2}$, Şafak YILDIZHAN ${ }^{2}$ \\ ${ }^{1}$ Çukurova Üniversitesi, Ceyhan Mühendislik Fakültesi, Makine Mühendisliği Bölümü, Adana \\ ${ }^{2}$ Çukurova Üniversitesi, Mühendislik-Mimarlık Fakültesi, Otomotiv Mühendisliği Bölümü, \\ Adana
}

Geliş tarihi: 27.01.2016

Kabul tarihi: 10.03 .2016

\begin{abstract}
In this study, performance and emission characteristics of a variable compression ratio (VCR) diesel engine fuelled with diesel fuel and diesel-biodiesel-alcohols blends have been evaluated in detail. The results of performance and emission characteristics of fuel blends were compared with low sulphur diesel fuel. Experimental study showed that biodiesel and alcohol addition to diesel fuels slightly affects the performance, combustion and emissions characteristics of the engine. The results showed that the increasing biodiesel ratio in the blend resulted in decrease of brake thermal efficiency and increment of specific fuel consumption (SFC). Furthermore, it was revealed that addition of alcohols and biodiesel fuel decreased carbon monoxide emission and increased $\mathrm{NO}_{\mathrm{x}}$ and carbon dioxide emissions.
\end{abstract}

Keywords: Performance, Emission, Butanol, Ethanol, Biodiesel

\section{Dizel, Dizel-Biyodizel-Alkol Yakıt Karışımlı Sıkıştırma Oranı Değişen Bir Dizel Motorun Performans ve Emisyon Karakteristiklerinin Değerlendirilmesi}

\section{Özet}

Bu çalışmada, sıkıştırma oranı değiş̧irilebilir dizel ve dizel-biyodizel-alkol karışımları kullanılan bir dizel motorun performans ve emisyon özellikleri ayrıntılı olarak değerlendirilmiştir. Yakıt karışımlarının performans ve emisyon karakteristik sonuçları, düşük kükürtlü dizel yakıt ile karşıllaştırılmıştır. Deneysel çalışma, dizel yakıtlara biyodizel ve alkol ilavesinin motor performansını, yanma ve emisyon özelliklerini çok az etkilediğini göstermiştir. Sonuçlar, karışımdaki biyodizel oranı artışının, ısıl verimde azalışa ve özgül yakıt tüketiminde (SFC) ise ait artışa neden olduğunu göstermiştir. Ayrıca, alkol ve biyodizel yakıt ilavesinin karbon monoksit emisyonunu azalttığını ve $\mathrm{NO}_{\mathrm{x}}$ ve karbon dioksit emisyonlarını ise arttırdığını ortaya çıkarmıştır.

Anahtar Kelimeler: Performans, Emisyon, Bütanol, Etanol, Biyodizel.

\footnotetext{
* Yazışmaların yapılacağı yazar: Ali KESKİN, Mühendislik Mimarlık Fakültesi, Otomotiv Mühendisliği Bölümü, Adana.akeskin@cu.edu.tr
} 


\section{INTRODUCTION}

After the oil crisis of the 1970 s, research interests on the internal combustion engines have been explored in the area of alternate fuels, which are renewable, locally available, environment friendly [2]. It is well known that transport is almost totally dependent on fossil particularly petroleum based fuels such as gasoline, diesel fuel, liquefied petroleum gas, and compressed natural gas. As the amount of available petroleum decreases, the need for alternate technologies to produce liquid fuels that could potentially help prolong the liquid fuels culture and mitigate the forthcoming effects of the shortage of transportation fuels increases. There are several reasons for biofuels to be considered as relevant technologies by both developing and industrialized countries. They include energy security reasons, environmental concerns, foreign exchange savings, and socioeconomic issues related to the rural sectors of all countries in the world. Biofuels have become more attractive recently because of its environmental benefits [2-8].

Biodiesel is a renewable energy source which is produced with transesterification reaction [9-12]. Biodiesel can be produced from various feedstocks such as vegetable oils, animal fats and even from waste oils. Many researchers investigated various feed stocks for biodiesel production [13-15]. Many vegetable oils such as pomace oil [16], soybean oil [17], castor oil [18], etc. have been used for producing biodiesel fuel.

Since renewable energy sources has been popular to investigate researchers also focused on alcohol which are renewable energy sources. Alcohols as additives to biodiesel-diesel blends were investigated in terms of performance and emission characteristics in diesel engines by many authors. It was reported that the use of alcohol blends up to $20 \%$ does not usually require any important modification [19]. It has been shown that alcoholbiodiesel blends with $10 \%$ and $15 \%$ alcohol concentration increase $\mathrm{HC}$ and $\mathrm{CO}$ emissions while $5 \%$ alcohol addition to biodiesel fuels decrease these emissions [20]. Most of the researchers have used diesel alcohol blends with a small percentage of ethanol, methanol and propanol [21-23].

In this study effect of biodiesel and alcohol addition to diesel fuel has been investigated experimentally. Experiments were conducted with diesel fuel and blends of diesel, false flax biodiesel, ethanol and butanol fuels. Experiments were conducted at partial load condition (\%60 load).

\section{MATERIAL AND METHOD}

The experimental study was conducted in Petroleum Research and Automotive Engineering Laboratories of the Department of Automotive Engineering at Cukurova University.

\subsection{Test Fuels}

False flax (Camelina Sativa) oil was used as raw material for biodiesel production. The samples of crude oils were supplied from a local oil company, Gaziantep, Turkey. Methyl ester samples were produced via transesterification method. In the reactions, methyl alcohol and sodium hydroxide $(\mathrm{NaOH})$ were used as reactant and catalyst. In order to determine best production condition, transesterification reactions were carried out in a spherical glass reactor equipped with reflux condenser, stirrer and thermometer. In the reactions, molar ratio of alcohol to oil was $6: 1$. The reaction was performed with methanol $20 \mathrm{wt} \%$, and sodium hydroxide $0,5 \mathrm{wt} \%$. Methanol and sodium hydroxide were mixed in order to obtain sodium methoxide. Then, sodium methoxide and oil samples were mixed in the reactor. The mixtures were heated up to $60^{\circ} \mathrm{C}$ and kept at this temperature for 90 minutes by stirring. After the reaction period, the crude methyl esters were waited at separating funnel for 8 hours. And then, crude glycerine was separated from methyl ester. Finally, the crude methyl esters were washed by warm water until the washed water became clear and dried at $105^{\circ} \mathrm{C}$ for 1 hour. Finally washed and dried methyl 
esters were passed through a filter and false flax methyl ester (FME) was obtained. Figure 1 presents the biodiesel production steps schematically. After refining the biodiesel, biodiesel, diesel and alcohols were blended. The test fuels were diesel fuel and diesel-biodiesel- alcohols blends. Test fuels weredenote as D (diesel fuel), B10A5 $(85 \%$ diesel+ $10 \%$ biodiesel $+2,5 \%$ ethanol $+2,5 \%$ butanol), and B20A5 (75\% diesel $+20 \%$ biodiesel $+2,5 \%$ ethanol $+2,5 \%$ butanol $)$.

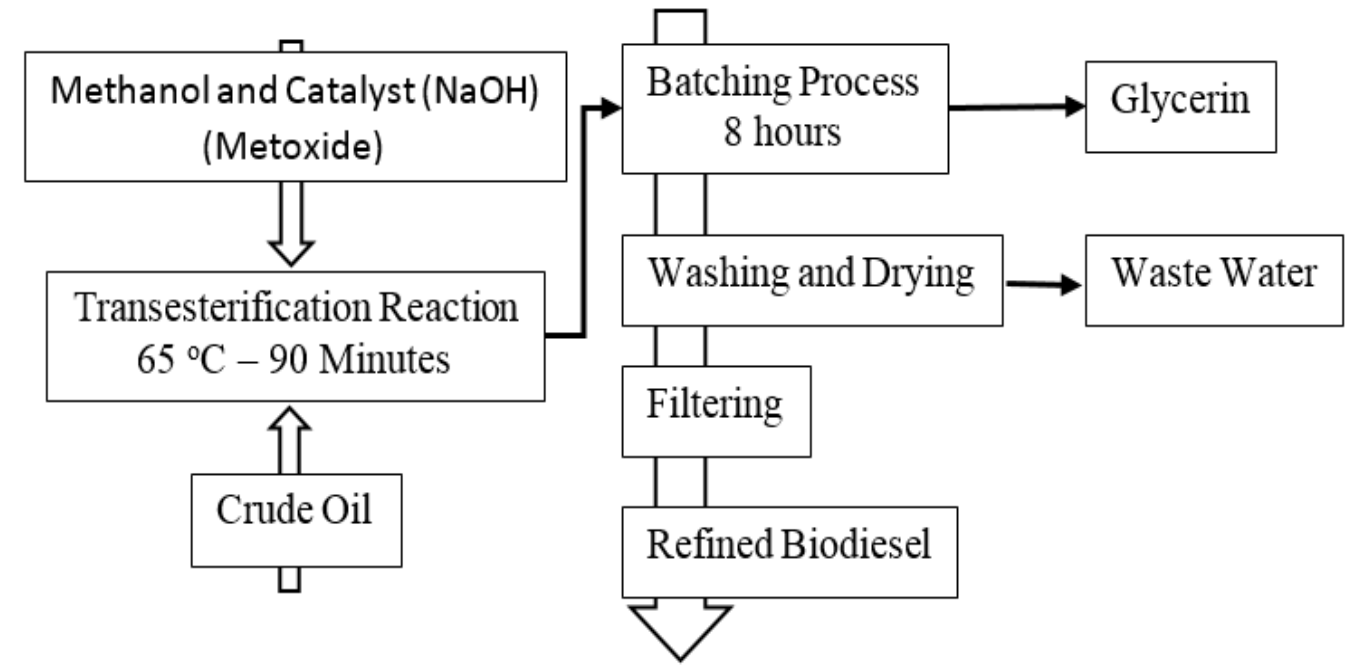

Figure 1. Biodiesel production processes

The psychical properties of the test fuels and oil were measured before testing them in the engine. Instruments used for analyzing the products were; Zeltex ZX 440 NIR petroleum analyzer with an accuracy of \pm 0.5 for determining cetane number; Tanaka AFP-102 for cold filter plugging point; Tanaka AKV-202 Auto Kinematic Viscosity test for determining the viscosity; Kyoto electronics DA-130 for density measurement, Tanaka flash point control unit FC-7 for flash point determination and IKA Werke C2000 bomb calorimeter for determination of heating value. The fuel quality measurements were fulfilled according to TS EN 14214 and EN 590 standards.

\subsection{Engine Specifications}

Engine experiments were conducted on a single cylinder, four strokes, naturally aspirated, water cooled, variable compression multi fuel engine. Technical specifications of the engine were given in Table 1. Schematic representation of test rig was shown in Figure 2. An eddy current dynamometer was used for determination of performance characteristics of the engine. Table 2 shows the technical specifications of the eddy current dynamometer. Experiments were conducted at constant speed of 1500 revolution per minute (rpm) and under partial load (60\% loads). The compression ratio of the engine was held as 16:1.

\subsection{Emission Devices}

MRU Air Delta $1600 \mathrm{~V}$ mobile exhaust gas analyzer was used to measure exhaust emissions. Emission data was collected with the help of analyzer software. Accuracy of the gas analyzer is $\pm 10 \mathrm{ppm}$ for $\mathrm{CO}, 1 \%$ for $\mathrm{CO}_{2}$ and $\pm 1 \mathrm{ppm}$ for $\mathrm{NO}_{\mathrm{x}}$.Table 3 show measurement ranges, 
Evaluation of Performance and Emission Characteristics of a VCR Diesel Engine Fuelled with Diesel Fuel and Diesel-Biodiesel-Alcohol Blends

Table 1. Technical specifications of the variable compression ratio (VCR) engine

\begin{tabular}{|l|l|}
\hline Brand & Kirloskar Oil Engines \\
\hline Model & 240 \\
\hline Configuration & Single Cylinder \\
\hline Type & Four Stroke, Water Cooled \\
\hline Displacement & $661 \mathrm{cc}$ \\
\hline Bore & $87,5 \mathrm{~mm}$ \\
\hline Stroke & $110 \mathrm{~mm}$ \\
\hline Maximum/Minimum Operating Speed & $2000 / 1200 \mathrm{rpm}$ \\
\hline Power & $3,5 \mathrm{Kw} @ 1500 \mathrm{rpm}$ \\
\hline Compression Ratio (CR) range & $12: 1-18: 1$ \\
\hline Injection Variation & $0-25 \mathrm{Deg}$ BTDC \\
\hline Peak Pressure & $77,5 \mathrm{~kg} / \mathrm{cm}^{2}$ \\
\hline Weight & $160 \mathrm{~kg}$ \\
\hline Combustion Principle & Compression Ignition \\
\hline
\end{tabular}

Table 2. Technical specifications of the dynamometer

\begin{tabular}{|l|l|}
\hline Model & AG10 \\
\hline Make & Saj Test Plant Pvt. Ltd. \\
\hline Water inlet & $1.6 \mathrm{bar}$ \\
\hline Torque & $11.5 \mathrm{Nm}$ \\
\hline Hot coil voltage max. & 60 \\
\hline Continuous current amps & 5 \\
\hline Speed max. & $10000 \mathrm{rpm}$ \\
\hline Load & $3,5 \mathrm{~kg}$ \\
\hline Weight & 130 \\
\hline
\end{tabular}

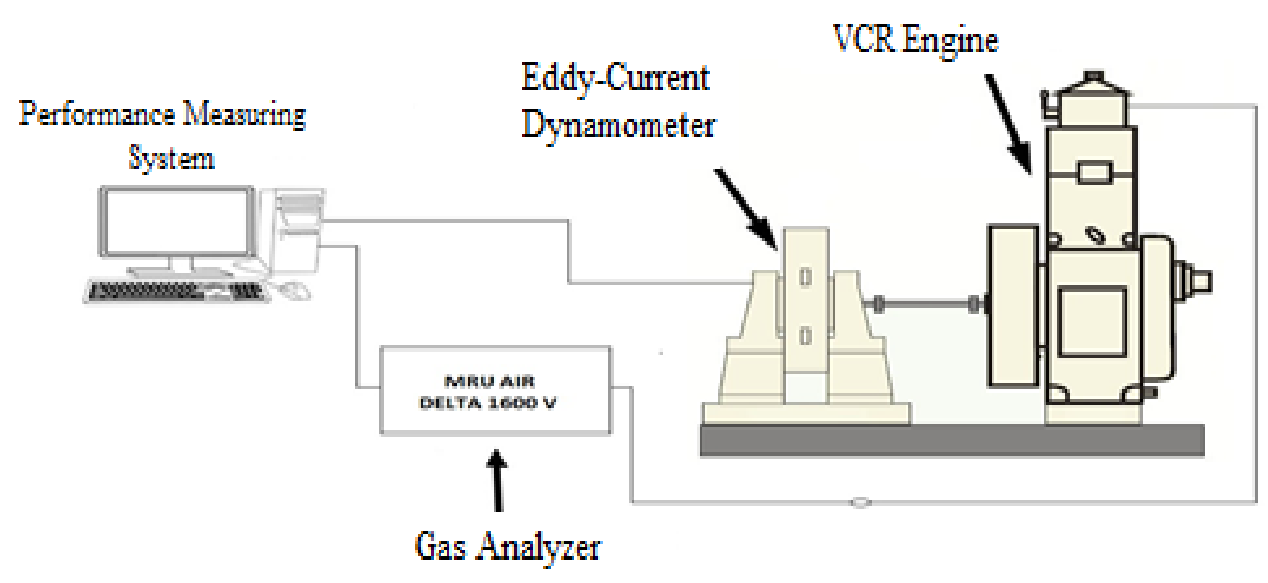

Figure 2. Schematic representation of test-rig 
Table 3. Measurement ranges, accuracy and resolution values of emission device

\begin{tabular}{|l|l|}
\hline Specification & $0-10 \%$ \\
\hline $\mathrm{CO}$ & $0-20 \%$ \\
\hline $\mathrm{CO}_{2}$ & $0-20000 \mathrm{ppm}$ \\
\hline $\mathrm{HC}$ & $0-22 \%$ \\
\hline $\mathrm{O}_{2}$ & $0-4000 \mathrm{ppm}$ \\
\hline $\mathrm{NO}$ & $0-1000 \mathrm{ppm}$ \\
\hline $\mathrm{NO}_{2}$ & $0-9,99$ \\
\hline Lambda & $\begin{array}{l}\text { According to } \\
\text { OIML-class } 1\end{array}$ \\
\hline Accuracy & $5^{\circ}-45^{\circ} \mathrm{C}$ \\
\hline Ambient Temperature & Max $650^{\circ} \mathrm{C}$ \\
\hline Exhaust Gas Temperature & \\
\hline
\end{tabular}

accuracy and resolution values of emission device and smoke meter, respectively.

\section{RESULT and DISCUSSION}

\subsection{Fuel Properties}

In general, false flax oil contains unsaturated fatty acids which are important advantages for the fuel properties of biodiesel such as lower pour point [24]. Fuel properties of false flax oil, false flax methyl ester (FFME) and its blends with diesel fuel were shown in Table 4. The density of biodiesel samples were found higher than that of diesel fuel so the blend fuels had higher density than that of diesel fuel.

Table 4. Fuel properties of test fuels

\begin{tabular}{|l|l|l|l|l|l|l|l|}
\hline Properties & $\begin{array}{l}\text { Diesel } \\
\text { fuel }\end{array}$ & EN590 & FME & B10A5 & B20A5 & $\begin{array}{l}\text { ASTM } \\
\text { D 6751 }\end{array}$ & EN 14214 \\
\hline $\begin{array}{l}\text { Density, } \\
\mathrm{kg} / \mathrm{m}^{3}\end{array}$ & 837 & $820-845$ & 886 & 0,835 & 0,841 & - & $860-900$ \\
\hline $\begin{array}{l}\text { Cetane } \\
\text { Number }\end{array}$ & 59,47 & Min 51 & 51 & 53,173 & 52,832 & Min 47 & Min 51 \\
\hline CFPP, ${ }^{\circ} \mathrm{C}$ & -11 & - & -10 & -13 & -12 & - & $\begin{array}{l}\text { Summer }<4,0 \\
\text { Winter <- } 1,0\end{array}$ \\
\hline $\begin{array}{l}\text { Lower heating } \\
\text { value, } \mathrm{kJ} / \mathrm{kg}\end{array}$ & 45,856 & - & 39,048 & & & - & - \\
\hline $\begin{array}{l}\text { Kinematic } \\
\text { viscosity, } \\
\text { mm }^{2} / \mathrm{s}\end{array}$ & 2,76 & $2,0-4,5$ & 4,38 & 3,07 & 3,21 & $1,9-6,0$ & $3,5-5,0$ \\
\hline Flash point ${ }^{\circ} \mathrm{C}$ & 79,5 & Min 55 & $>140$ & - & - & Min 93 & Min 120 \\
\hline
\end{tabular}


The heating value of biodiesel samples and biodiesel-diesel-alcohol blends were lower than diesel fuel. Cetane number of FME was measured as 51 which satisfy the American and European Biodiesel Standards. The temperature at which is the lowest temperature of the standardized volume of fuel can pass through a standardized filter is determined by cold filter plugging point (CFPP). Also CFPP is a significant property which is relative with pour point. Analysis showed that CFPP points of biodiesel samples and their blends with diesel fuel were close to the diesel fuel which is an important property for cold working situations. Analysis showed that FME and dieselbiodiesel -alcohol blends had higher viscosity than diesel fuel.

\subsection{Performance Characteristics}

Brake thermal efficiency (BTHE) which is defined as ratio of engine power output to heat input of fuel is one of the most important performance criteria for internal combustion engines [25]. Experiments showed that addition of biodiesel and alcohols to diesel fuel caused a slight decrement in the terms of BTHE. The main cause of that result is the lower Cetane numbers of the blend fuels. The low Cetane number causes to prolong ignition delay. According to standard combustion process, thissituation change characteristic of heat release and increasing ratio of pressure in the engine combustion chamber. In other words, lower Cetane number of blend fuels cause deterioration of combustion characteristics which decrease brake thermal efficiency values of the engine. Decreasing BTHE also results with higher specific fuel consumption (SFC). $\mathrm{SFC}$ is the measure of fuel consumption to produceunit power. Experiment results showed that diesel-biodiesel-alcohols blends usage caused a slight increment in the means of SFC. In comparison with diesel fuel test fuel, B10A5 decreased BTHE 2,6\% and test fuel B20A5 decreased BTHE6,09\%. Also, results of experiments showed that B10A5 test fuel and B20A5 test fuel increased SFC 3,41\% and 6,89\% compared to diesel fuel, respectively. Figure 3 shows the brake thermal efficiency results of test fuels and Figure 4 indicates the specific fuel consumption (SFC) values.

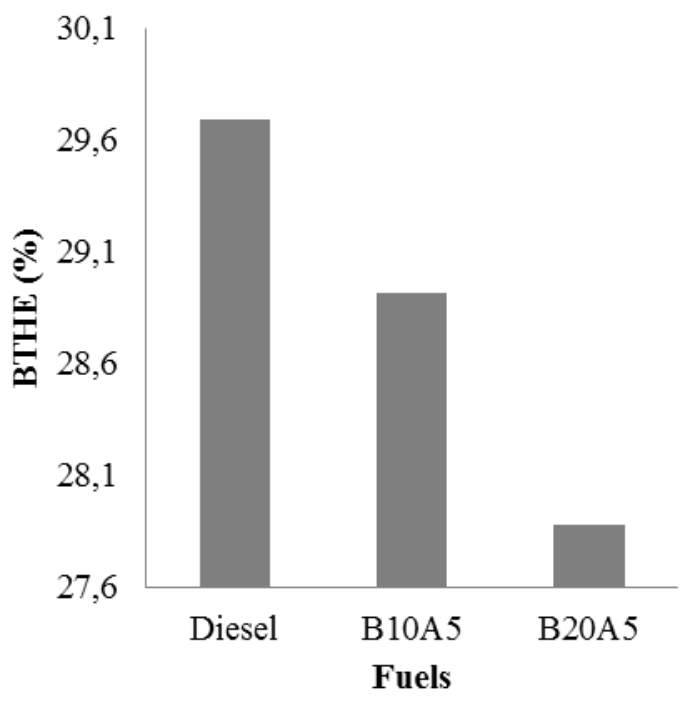

Figure 3. BTHE values of test fuels

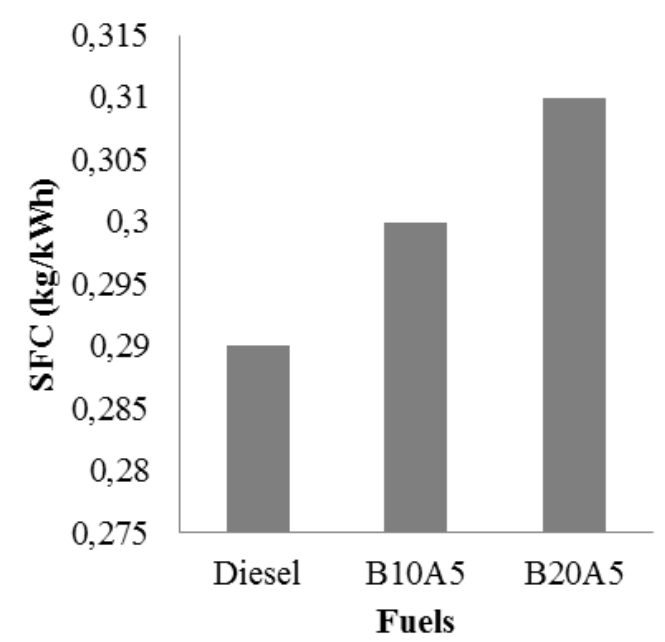

Figure 4. SFC values of test fuels 
Exhaust gas temperature (EGT) is a very important criteria for analyzing the performance and combustion characteristics of a fuel. Addition of biodiesel and alcohols resulted with higher EGT. This result is mainly caused by extra oxygen $\mathrm{O}_{2}$ content of biodiesel and alcohols in their compositions compared to diesel fuel. Extra oxygen content improves combustion and so exhaust gas temperature rises. EGT of test fuel were 103,121 and $125,04^{\circ} \mathrm{C}$ for diesel, B10A5 and B20A5 fuels, respectively. Figure 5 shows the EGT of test fuels.

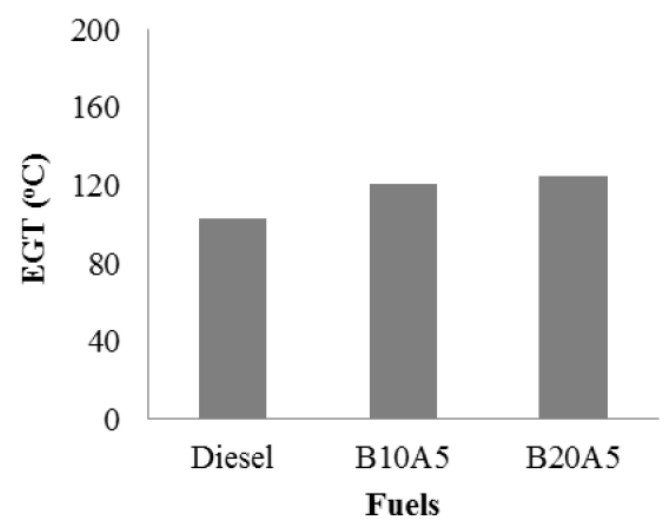

Figure 5. EGT values of test fuels

\subsection{Emission Characteristics}

Figure 6 shows the $\mathrm{CO}$ emission results of the experiments. It is clear that blending diesel fuel with biodiesel and alcohols decreased $\mathrm{CO}$ emissions significantly. The test engine emitted lower CO emissions when the B10A5 and B20A5 fuel instead diesel fuel. The main reason of this result is extra oxygen content of biodiesel and alcohols. B10A5 and B20A5 usage decreased CO emissions $9,09 \%$ and $28,78 \%$ compared to diesel fuel, respectively.

Variation of $\mathrm{CO}_{2}$ emissions of experiments are shown in Figure 7. It can be seen from the graphs addition of biodiesel and alcohols to diesel fuel resulted in higher $\mathrm{CO}_{2}$ emissions since extra oxygen contents of biodiesel and alcohols improve the combustion and thus, $\mathrm{CO}_{2}$ compositions are converted to $\mathrm{CO}_{2}$ emissions. B10A5 and B20A5 increased $\mathrm{CO}_{2}$ emissions up to $6,3 \%$ and $11,69 \%$ in comparison with diesel fuel, respectively.

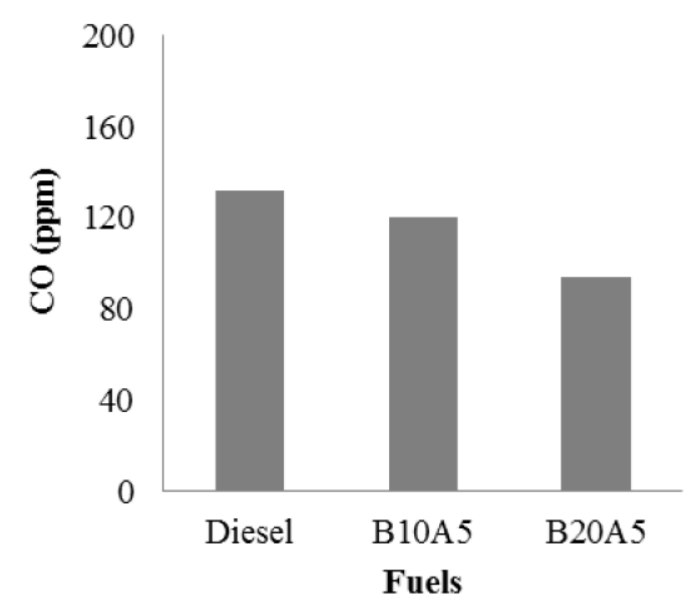

Figure 6. CO emission values of test fuels

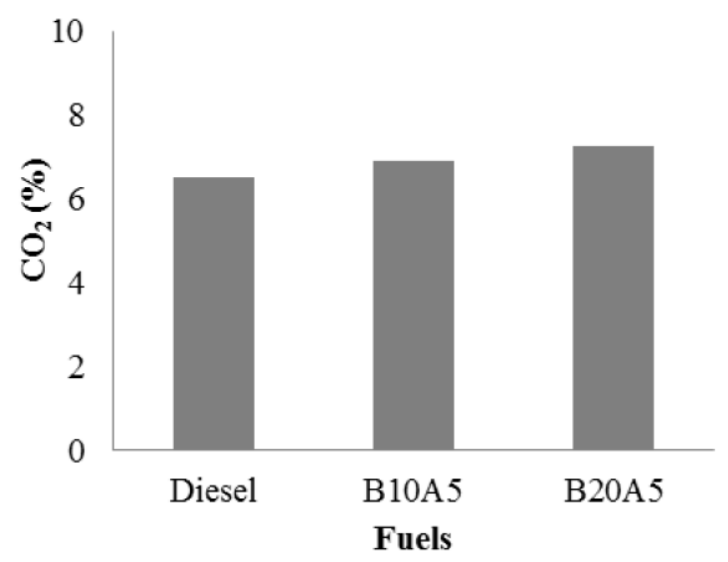

Figure 7. $\mathrm{CO}_{2}$ emission values of test fuels

$\mathrm{NO}_{\mathrm{x}}$ results of all test fuels are shown in Figure 8. Diesel-biodiesel-alcohol blends increased $\mathrm{NO}_{\mathrm{x}}$ emissions since combustion temperature of biodiesels are higher than that of diesel fuel. Higher cylinder temperatures cause more formation of $\mathrm{NO}_{\mathrm{x}}$ emissions. Thus, the maximum $\mathrm{NO}_{\mathrm{x}}$ emissions are emitted by the engine when B20A5 fuel is used as a fuel. B10A5 and B20A5 
Evaluation of Performance and Emission Characteristics of a VCR Diesel Engine Fuelled with Diesel Fuel and Diesel-Biodiesel-Alcohol Blends

increased $\mathrm{NO}_{\mathrm{x}}$ emissions $21,42 \%$ and $47,61 \%$ compared to diesel fuel, respectively.

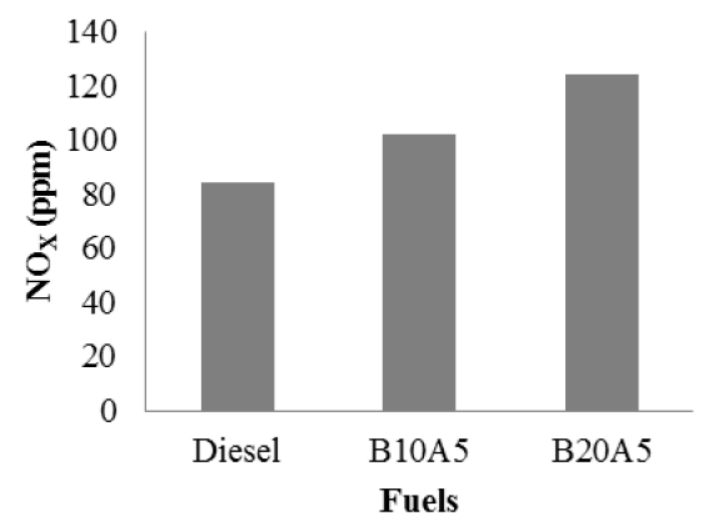

Figure 8. $\mathrm{NO}_{\mathrm{x}}$ emission values of test fuels

\section{CONCLUSION}

This study was carried out in order to find out the performance and emission characteristic of a diesel engine at partial load condition fuelled with diesel and diesel-biodiesel-alcohols blends. During the experiments the engine compression ratio was set as $16: 1$ and engine load was $60 \%$.

According to test results, the following conclusion can be summarized;

- Maximum mean BTHE (29.69\%) was obtained when engine was fuelled with low sulphur diesel. Biodiesel and alcohol additives (B10A5 and B20A5) decreased BTHE.

- Usage of biodiesel and alcohols caused increase in specific fuel consumption.

- Exhaust gas temperature was increased with B10A5 and B20A5. Extra oxygen content of biodiesel and alcohols resulted in higher exhaust gas temperatures.

- CO emission values were decreased when engine fueled with B10A5 and B20A5 fuels due to extra oxygen content of fuels when compared to diesel fuel.

- B10A5 and B20A5 fuels caused to increase of $\mathrm{CO}_{2}$ values compared to diesel fuel.

- The higher combustion temperatures of B10A5 and B20A5 fuels caused to increase of $\mathrm{NO}_{\mathrm{x}}$ values significantly.

\section{ACKNOWLEDGEMENT}

We would like to thank Ç.Ü. Scientific Research Project Department for their support (Project No. ID 5987).

\section{REFERENCES}

1. Demirbas, A., 2005. Biodiesel Production from Vegetable Oils via Catalytic and Non-Catalytic Supercritical Methanol Transesterification Methods. Progress in Energy and Combustion Science 31:466-87.

2. Balat, M., 2009. New Biofuel Production Technologies. Energy Educ. Sci. Technol. Part A;22:147-61.

3. Demirbas, C., 2009. The Global Climate Challenge: Recent Trends in $\mathrm{CO}_{2}$ Emissions fromFuel Combustion. Energy Educ. Sci. Technol. Part A, 22:179-93.

4. Humbad, A., Kumar, S., 2009. Babu,BV., Carbon Credits for Energy Self Sufficiency in Rural India-ACase Study. Energy Educ. Sci. Technol. Part A, 22:187-97.

5. Dincer, K., 2008. Lower Emissions from Biodiesel Combustion. Energy Sources Part A, 30:963-8.

6. Demirbas, A., Dincer, K., 2008. Sustainable Green Diesel: a Futuristic View. EnergySources Part A. 30:1233-41.

7. Hacisaligoglu, S., 2009. Ethanol-Gasoline and Ethanol-Diesel Fuel Blends. Energy Educ.Sci. Technol. Part A, 22:133-46.

8. Demirbas, B., 2009. Biofuels for Internal Combustion Engines. Energy Educ. Sci. Technol.Part A, 22:117-32.

9. Ozcanli, M., Serin, H., Aydin, K., Serin, S., 2011. Ricinus Communis (Castor Oil) Methy 1Ester as a Natural Additive for Biodiesel Fuels. Energy Education Science and Technology Part A: Energy Science and Research;27(2):331-336.

10. Serin, H., Ozcanli, M., Gokce., M.K., Tuccar, G., 2013. Biodiesel Production from Tea Seed (Camellia Sinensis) Oil and Its Blends with Diesel Fuel. International Journal of Green Energy, 10(4):370-377.

11. Yildizhan, S., Yasar, A., 2015. Performance and Emission Characteristics of Diesel Engine 
Operating on Biodiesel and Biodiesel Blended with Methanol and Propanol. International Journal of Scientific and Technological Research, 1(1):270-278.

12. Demirbas, A., 2010. Tea Seed Upgrading Facilities and Economic Assessment of Biodiesel Production from Tea Seed Oil. Energy Conversion and Management;51:25952599.

13. Anwar, F., Rashid,U.,Ashraf,M., Nadeem , M., 2010. Okra (Hibiscus esculentus) Seed Oil for Biodiesel Production. Applied Energy;87:779785.

14. Balusamy, T., Marappan, R., 2010. Effect of Injection Time and Injection Pressure on CIEngine Fuelled with Methyl Ester of Thevetiaperuviana Seed Oil. International Journal of Green Energy; 7:397-409.

15. Saribiyik, O.Y., 2010. Ozcanli, M., Serin, H., Serin, S., Aydin, K., Biodiesel Production from Ricinuscommunis Oil and Its Blends with Soybean Biodiesel.Strojniškivestnik- Journal of Mechanical Engineering, 56:811-816.

16. Caynak, S., Guru, M., Bicer, A., Keskin, A., Içingur, Y., 2009. Biodiesel Production from Pomace Oil and Improvement of Its Properties with Synthetic Manganese Additive. Fuel;88:534-538.

17. Canakci, M., Gerpen, J.H.V., 2003. Compression of Engine Performance and Emission for Petroleum Diesel Fuel, Yellow Grease Biodiesel, and Soybean Oil Biodiesel. Trans. ASAE;46:937-44.

18. Ozcanli, M., Serin, H., Aydin, K., Serin, S., 2011. Ricinus Communis (Castor Oil) Methyl Ester as a Natural Additive for Biodiesel Fuels. Energy Education Science and Technology Part A: Energy Science and Research;27(2):331-336.

19. Karabektas, M., Hosoz, M., 2009. Performance and Emission Characteristics of a Diesel Engine Using Isobutanol-Diesel Fuel Blends. Renewable Energy;34:1554-1559.

20. Yilmaz, N., 2012. Performance and Emission Characteristics of a Diesel Engine Fuelled with Biodiesel-Ethanol and Biodiesel-Methanol Blends at Elevated Air Temperatures. Fuel, 94:440-443.
21. Tsai, J.H., Chen, S.J., Huang, K.L., Lin, W.Y., Lee, W.J., Lin, C.C., Hsieh, L.T., Chiu, J.Y., Kuo, W.C., 2014. Emissions from a Generator Fuelled by Blends of Diesel, Biodiesel, Acetone, and Isopropyl Alcohol: Analyses of Emitted PM, Particulate Carbon, and PAHs. Science of the Total Environment;466:195202.

22. Yasin, M.H.M., Yusaf, T., Mamat, R., Yusop, A. F., 2014. Characterization of a Diesel Engine Operating with a Small Proportion of Methanol as a Fuel Additive in Biodiesel Blend. Applied Energy;114:865-873.

23. Yasin, M.H.M., Mamat, R., Yusop, A. F., Rahim, R., Aziz, A., Shah, L.A., 2013. Fuel Physical Characteristics of Biodiesel Blend Fuels with Alcohol as Additives. Procedia Engineering;53:701-706.

24. Yildizhan, S., Serin, H., 2015. Biodiesel Production from False Flax (CamelinaSativa) Oil and Its Blends with Diesel Fuel. The Journal of Macro Trends in Energy and Sustainability;3:24-30.

25. Sayin, C., Balki, M.K., 2015. Effect of Compression Ratio on the Emission, Performance and Combustion Characteristics of a Gasoline Engine Fuelled with IsoButanol/Gasoline Blends. Energy;82:550-555. 
